\title{
ANALYSIS OF CRITICAL LAND USING FOREST CANOPY DENSITY METHOD IN THE AGROPOLITAN DEVELOPMENT AREA OF LAMONGAN REGENCY, INDONESIA
}

\author{
Ade Irwansah \\ Sido Dadi Farmers Group, Embonggede Hamlet, Kuwurejo Village, Bluluk District
}

\begin{abstract}
Abstrak: Lahan kritis merupakan salah satu bentuk dari lahan terdegradasi. Kondisi biofisik lahan yang cenderung menurun menyebabkan penurunan produktivitas pertanian, lingkungan, dan ketersediaan pangan dan di sebabkan oleh pemanfaatan sumber daya alam yang kurang bijaksana. Penelitian ini diadakan di daerah Kabupaten Lamongan bagian selatan yang berfokus pada agropolitan metode sawah tadah hujan yang mengalami beberapa penurunan hasil penen dalam tahun terakhir. Metode penelitian berupa analisis persebaran lahan kritis dengan menggunakan Sistem Informasi Geografi yang dibagi ke dalam tahap-tahap utama yaitu: pembangunan basis data dan analisis data, yang diawali dengan pengumpulan data, peta pendukung dan analisis. Tingkat kekritisan lahan wilayah agropolitan di Kabupaten Lamongan dibagi atas 5 kategori, yakni Tidak Kritis, Potensial Kritis, Agak Kritis, Kritis serta Sangat Kritis namun kategori sangat kritis ternyata tidak ada lahan yang masuk kategori tersebut sehingga hanya ada 4 kategori lahan kritis yang menunjukan bahwa lahan tidak kritis sebesar 0,24\%, Potesial Kritis 74,80\%, agak kritis 24,77\%, dan Kategori Kritis 0,19\%

Kata Kunci : Lahan Kritis, Forest Canopy Density, Agropolitan
\end{abstract}

\begin{abstract}
Critical land is a form of degraded land. The biophysical condition of the land that tends to decline causes a decrease in agricultural productivity, the environment, and food availability and is caused by the unwise use of natural resources. This research will be conducted in the southern part of Lamongan Regency which focuses on agropolitan rainfed rice fields which have experienced some decline in harvest yields in the last year. The research method is an analysis of the distribution of critical land using a Geographic Information System which is divided into main stages, namely: database development and data analysis, which begins with data collection, supporting maps, and literature study. The critical level of land in agropolitan areas in Lamongan Regency is divided into 5 categories, namely Not Critical, Potentially Critical, Slightly Critical, Critical and Very Critical but the very critical category turns out that there is no land that falls into that category so there are only 4 categories of critical land which shows that the land is classified as critical. non-critical area is $0.24 \%$, Critical Potential area is $74.80 \%$, somewhat critical category covers $24.77 \%$, and Critical Category 0,19\% of the area. Keywords: Critical Land, Forest Canopy Density, AgropolitanAbstrak:
\end{abstract}

\section{A. INTRODUCTION}

Critical land is a form of degraded land. Land degradation is a process of decreasing land productivity which is temporary or permanent which is characterized by a decrease in physical, chemical and biological properties. Critical land is a form of degraded land (Dariah et al. 2004). According to (Nugroho and Prayogo 2008), land degradation is a temporary or permanent process of decreasing land productivity

Corespondency address : 
which is characterized by a decrease in soil physical, chemical and biological properties. The biophysical condition of land that tends to decline causes a decrease in agricultural productivity, the environment, and food availability. In general, critical land is an indicator of environmental degradation as a result of various types of unwise use of land resources.

Hyrologically critical land is land whose condition is such that the land is no longer able to maintain its function as a regulator of the water system. This happens because of the disruption of the land's ability to hold, absorb and store water. This situation is actually closely related to the physical critical state previously stated and can be a result of the physical criticality. Hydroorological critical land can be seen in the field from the amount of vegetation that grows on the soil. Most types of vegetation are no longer able to grow and develop well in this hydro-orological critical condition. (Rachman 2006).

Based on Law Number 26 of 2007 concerning Spatial Planning, it is mandated that every region in Indonesia is expected to be able to allocate land for food agriculture on an eternal basis through a Regional Regulation on Regional Spatial Planning (RTRW) so that the sustainability of food agricultural land can be maintained (Karenina, 2016:2- 3; Sakti et al. 2013: 56-57).
Lamongan Regency is designated as one of the agropolitan development areas in East Java through the Decree of the Lamongan Regent Number: 188/284/Kep/413. 013/2008 concerning Determination of Agropolitan Area Centers in Lamongan Regency. Based on the Regional Regulation of Lamongan Regency Number 15 of 2011 concerning the Regional Spatial Plan of Lamongan Regency in 2011-2031 that in the development of the Agropolitan area, it is in the southern region of Lamongan Regency, which consists of 11 subdistricts including Tikung, Sarirejo, Kedung-pring, Modo, Sugio, Kembangbahu Districts. Sambeng, Bluluk, Mantup, Sukorame and Ngimbang Districts. Based on the Decree of the Regent of Lamongan Number: 188/284/Kep/413.013/2008.

Lamongan Regency is located in the province of East Java. The southern part of Lamongan is a rocky limestone mountain with moderate fertility. This area consists of the Districts of Mantup, Sambeng, Ngimbang, Bluluk, Sukorame, Modo. As an area that is a rain catchment area and is also a rain rice field, the sustainability of this area must be maintained, one of which is by regulating the use of land in this area. In addition, it is necessary to continuously know the condition of critical land in this southern area. 
On sloping land the risk of erosion and runoff is quite large. By providing protection to the soil in the form of terraces, planting crops on a contour, and using organic fertilizers in situ is a wise action in saving the environment in overcoming land degradation (Gardner and Gerrard. 2003; Andreas de Neergaard et al., 2008; Nyssen Jan. et al., 2009; Nurida and Law Kurnia, 2009). Therefore, the aspect of soil conservation is very important in creating a sustainable and sustainable environment.

The existence of accurate and new data (up to date) providing spatial information on the condition of critical land is very necessary in order to formulate a comprehensive and proportional management strategy and also make it easier to identify and map critical lands. With the development of information technology today, by utilizing digital data formats (maps) it will be easier to carry out needs analysis. Utilization of remote sensing for spatial analysis of critical land has been carried out in the West Bandung area with a regression method with Geographic Information Systems (GIS) using ArcGIS 10.2 software and Landsat 8 OLI imagery, which results in the criticality level of land in all protected areas has entered the moderately critical category and after a regression test was conducted, it was found that the prediction equation for the criticality level of land with good accuracy and it is known that the spatial data used as the critical land criteria has a significant effect on the criticality level of the land (Zetifarry, 2013).

Based on the description above, research on identifying critical land based on parameters for determining the criticality level of land by utilizing Landsat 8 OLI Imagery using Geographic Information Systems (GIS) and remote sensing which aims to determine the criticality value of land based on the criticality level of land in Lamongan Regency, determine the effect of land cover land, slope, erosion hazard level and land management on the criticality level of land in Lamongan Regency.

\section{B. METHOD}

This study uses a descriptive approach. The research method is an analysis of the distribution of critical land using a Geographic Information System which is divided into main stages, namely: database development and data analysis, which begins with data collection, supporting maps, and literature study.

The data referred to in this study are data related to research to be carried out and obtained in the field or from agencies/agencies related to research. Data collection is carried out in order to support the data processing process for the research carried out. The data in this research is spatial data. 
Lamongan Regency Administration Map, Scale 1:20000 (Source: Bappeda Lamongan). Lamongan Regency Land Cover Map 1:20000 (Source: Bappeda Lamongan). Map of soil type, 1:20000 scale (Source: Bappeda lamongan). 2019 Land Use Map Scale 1:20000 (image digitization). Rainfall map (source: Bappeda Lamongan.

1. Data Analysis

The pre-processing process is as follows

a. Radiometric correction.

b. Cropping the image using ArcGIS 10.2 software on Landsat 8 OLI images with the administrative boundary of Lamongan Regency.

c. Perform image sharpening / composite images with ArcGIS 10.2 software on Landsat 8 OLI images.

2. Processing as follows

a. Forest Canopy Density

b. How to find the density of vegetation, namely:

- Looking for AVI (Advanced Vegetation Index), using Landsat 8 OLI imagery.

- Looking for BI (Bare Soil Index), using Landsat 8 OLI imagery.

- Looking for SI (Shadow Index), using Landsat 8 OLI imagery.

- Find TI (Temperature Index), convert Digital Number to radiation value then calculate TI using Landsat 8 OLI imagery.
- Searching for VD, combining AVI and BI.

- Looking for ASI, combining IS and IT.

- Performing an integration model for VD and ASI using the FCD formula to produce a Forest Canopy Density (FCD) map.

3. The post-processing process is carried out by doing

a. Overlaying land cover maps, slope maps, vegetation density maps, erosion hazard level maps and land management results, using ArcGIS 10.2 to sum all criteria, get a total score and then adjust according to the Ministry of Forestry criteria, so that a map of the land criticality level is obtained. .

b. calculate the critical land index on the critical land criteria to determine the criticality level of each sub-district in Lamongan-Lamongan Regency.

\section{RESULT AND DISCUSSION}

\section{C.1. RESULT}

Forest Canopy Desity Analysis. Utilization of Landsat 8 OLI to calculate forest canopy density, with 4 parameters AVI, BI, SI and TI. Ti is the temperature index. Temperature Index (TI), obtained by using the formula to calculate TI in the equation by utilizing Band 10 (Long Wavelength InfraRed) on Landsat 8 OLI. The temperature index requires radiation correction in equation (1) with Qcal (DN value) for Landsat 8 OLI, namely 65535 , constants Qmax, Qmin, Lmax and Lmin, (Rikimaru, 2002). The four indices use 
band 2 (blue), band 3 (green), band 4 (red), band 5 (near infrared), band 6 (middle infrared 1), band 7 (middle infrared 2), and band 10 (middle infrared) on Landsat 8.

Advanced Vegetation Index (AVI) is an index that tests the chlorophyll characteristics of vegetation. The index uses the following equation:

$\mathrm{AVI}=(($ Band5 +1) $(256-$ Band4) $($ Band5 - Band4))1/3

Bare Soil Index (BI) is formulated using the middle infrared band, near infrared band, red band, and blue band. The response of open land, vacant land, and vegetation is enhanced through this index. The BI equation is as follows:

$(((\mathrm{B} 6+\mathrm{B} 4)(\mathrm{B} 5+\mathrm{B} 2)) /(((\mathrm{B} 6+\mathrm{B} 4)+(\mathrm{B} 5+\mathrm{B}$

2)) $\times 100+100$

Shadow Index (SI) is a calculation that tests the characteristics of shadows by utilizing spectral information from forest shadows, with the following formula:

$\mathrm{SI}=((256-$ Band2 $) \times(256-$ Band3 $) \mathrm{x}$ (256 - Band4)) $1 / 3$

Thermal Index (TI) is an index based on two factors that affect the relative coldness of conditions in the forest. The first factor is the shielding effect of the forest canopy which blocks and absorbs energy from the sun. The second factor is evaporation from the leaf surface which reduces heating.

Data on temperature are used to separate soil and non-tree shadows. The temperature calibration from the thermal infrared channel to the soil temperature value is obtained by first converting the digital value in the thermal channel to a radian value. After obtaining the radian value, then the conversion to brightness temperature is carried out in band 10 . The equation used to change the radian value is:

$\mathrm{T}=\mathrm{K} \_2 /\left(\ln \left(\mathrm{K} \_1 / \mathrm{L} \_\lambda+1\right)\right)$ (2.4).

Correlated with each other. The amount of vegetation increases along with the increase in shadow so that when the forest density increases, the shadow below it also increases which then causes the SI value to increase. Thermal Index increases when the quantity of vegetation decreases because when the ground is more exposed (indicating less vegetation cover) the temperature increases more. According to (Rikimaru 2002), the combination of the four indices used in FCD modeling will then produce a correlation between the four.

Analysis of Forest canopy Density in the Agropolitan area of Lamongan Regency The greater the value of forest canopy density, the smaller the parameter value we provide, because the denser the forest canopy, the smaller the criticality.

It can be explained that class I with forest density of 1.442806-1.553508 is 489.45 with a percentage of 0.94 percent, Forest Canopy Density Class II with a vegetation density of 9549.3 ha with a percentage of $18.41 \%$, Forest Canopy 
class Density III with a vegetation density of 41212 ha with a percentage of $79.45 \%$, in the Forest Canopy Density IV class classification with an area of 616.41 ha with a percentage of $1.19 \%$ and for forest canopy density $\mathrm{V}$ class with the smallest area of 4.22 ha.

Table 1. Land area of forest canopy desity

\begin{tabular}{llcc}
\hline \multirow{2}{*}{ Number } & Fcd class & Ha & Parge \\
\cline { 3 - 4 } & & 489,45 & 0,94 \\
\hline 1 & I & 9549,3 & 18,41 \\
\hline 2 & II & 41212 & 79,45 \\
\hline 4 & III & 616,41 & 1,19 \\
\hline 5 & IV & 4,22 & 0,01 \\
\hline & V & 51871,38 & 100,00 \\
\hline
\end{tabular}

With a percentage of $0.01 \%$. So with the analysis of the forest canopy density class, it can be explained that the one with the densest canopy density has a very low criticality of $0.94 \%$, while the area with the least dense canopy density is $0.01 \%$ in the agropolitan area of Lamongan Regency.

\section{C.2. DISCUSSION}

1. Critical Land Analysis
Source : source address Spatial analysis is carried out by overlaying several spatial data (determining parameters of critical land) to produce a new mapping unit that will be used as the unit of analysis. In each unit of analysis, an analysis of the attribute data is carried out. The results of the analysis are then linked to the spatial data to produce spatial data on critical land.

Table 2. Critical Land Area

\begin{tabular}{llcc}
\hline \multirow{2}{*}{ Number } & Class & \multicolumn{2}{c}{ Large } \\
\cline { 3 - 4 } & Not critical & 125,4418 & Persentase \\
\hline 1 & Potential critical & 38736,37 & 0,24 \\
2 & Less critical & 12827,92 & 74,80 \\
3 & Critical & 100,2828 & 24,77 \\
4 & Total & 51790,01 & 0,19 \\
\hline & & & 100 \\
\hline
\end{tabular}

Source : source address

The critical land value is obtained by using the overlay method on critical land parameters, namely forest canopy density (FCD), erosion hazard level, and slope. Based on the Standard Documents and Criteria for Forest and Land Rehabilitation Attachment to the Decree of the Minister of Forestry No. 20/KptsII/2001 (Document Standards and 
Criteria for RHL), the classification of critical land can be divided into 5 classes as follows Not critical, Critical potential, Somewhat critical, Critical, Very critical. The critical level of land in the agropolitan area in Lamongan Regency is divided into 5 categories, namely Not Critical, Potentially Critical, Slightly Critical, Critical and Very Critical but the very critical category turns out to be no land that falls into that category so there are only 5 categories of critical land in the area. Agropolitan Lamongan Regency. The results showed that the criticality level of land in Lamongan Regency includes non-critical to critical with uncritical land area of 125.44 ha with a percentage of 0.24 , Critical Potential area of 38736.37 ha with a percentage of $74.80 \%$, category of moderately critical area of 12827 with the percentage is $24.77 \%$, and the Critical Category is 100.28 ha with a percentage of $0.19 \%$. It can be concluded that the critical land in the agropolitan area of Lamongan Regency is only $0.19 \%$. Critical land in lamongan is affected by steep slopes due to limestone hills and high rainfall intensity.

The distribution of critical land with the largest non-critical class criteria is in Modo sub-district with an area of 83.59 ha, the largest potential critical land class criteria is in Sambeng sub- district with an area of 9854.84 ha, theargest moderately critical land class criteria is in Sambeng sub-district with an area of $5280.79 \mathrm{ha}$, and the criteria for the largest critical land class are in Sambeng District with an area of 73.42 Ha.

\section{CONCLUSION}

Based on the results of research and discussion on "Analysis of Agropolitan Area Development in the Development Area Unit (SWP) V of Lamongan Regency", several conclusions can be drawn as follows:

1. The results of the analysis show that the criticality level of land in Lamongan Regency includes non-critical to critical with uncritical land area of $125.44 \mathrm{Ha}$ with a percentage of 0.24 , Critical Potential area of 38736.37 ha with a percentage of $74.80 \%$, Category is somewhat critical area 12827 with a percentage of $24.77 \%$, and the Critical Category covers an area of 100.28 ha with a percentage of $0.19 \%$. It can be concluded that the critical land in the agropolitan area of Lamongan Regency is only $0.19 \%$.

2. The results of the analysis of critical land with the largest non-critical class criteria are in Modo sub-district with an area of 83.59 ha, the largest potential critical land class criteria are in Sambengn District with an area of 9854.84 ha, the largest moderately critical land class criteria are in Sambeng 
District. with an area of 5280.79 ha, and the largest critical land class criteria are in Sambeng District with an area of 73.42 Ha.

3. The sub-district that dominates the criteria for the largest critical land is in Sambeng District, namely the critical land class criteria (potentially critical, moderately critical and critical)

\section{E. RECOMENDATION}

Based on the conclusions of the research above, some suggestions can be given to parties related to the development of agropolitan areas in the Development Area Unit (SWP) V of Lamongan Regency, namely as follows:

1. The results of the analysis and conclusions from the analysis of critical land in the agropolitan area can be implemented through a program plan for the Lamongan Regency Agriculture and Plantation Service in synergy with the Lamongan Regional Planning and Development Agency

2. Identification of the distribution of critical land in the SWP V development area in Lamongan Regency is the basis for the entry of investors to invest in developing agriculture, industry with assistance from relevant government agencies.

3. Further research is needed using more complete and accurate data, including data on soil chemical properties so that the resulting land evaluation is more detailed and accurate.

\section{BIBLIOGRAPHY}

Dariah A, Rachman A, dan Kurnia U. 2004. Erosi dan Degradasi Lahan Kering di Indonesia. Bogor (ID). Puslittanak Badan Penelitian dan Pengembangan Pertanian, Departemen Pertanian

Gardner R.A.M., and A.J. Gerrard. 2003." Runoff and soil erosion on cultivated rainfed terraces in the Middle Hills of Nepal". Applied Geography 23, 1. 23-45.

Nugroho S, P. Prayogo. 2008. Penerapan SIG Untuk Penyusunan Dan Analisis Lahan Kritis Pada Satuan Wilayah Pengelolaan DAS Agam Kuantum, Provinsi Sumatera Barat. Badan Pengkajian dan Penerapan Teknologi. Jakarta.

Karenina, A. (2016). Strategi perlindungan lahan pertanian pangan berkelanjutan di Kabupaten Tangerang. Jurnal Manajemen Pembangunan Daerah8(2): 1-9.

Rikimaru, A., Roy, P.S, dan Miyatake, S., (2002), Tropical Forest Cover Density Mapping, Journal of Tropical Ecology v43 (1) : 39-47.

Sakti, et al. (2013). Kajian pemetaan lahan pertanian pangan berkelanjutan (LP2B) di kabupaten purworejo. Jurnal ilmu tanah dan Agroklimatologi: 55-70Meniti Harapan. Jakarta (ID):PT.Duta Karya Swasta.

Zetifarry, R., (2013), Analisis Data Spasial Untuk Prediksi Lahan Kritis Menggunakan Metode Regresi Linier Berganda (Studi Kasus : Kawasan Hutan Lindung Kabupaten Bandung Bharat), Skripsi, Fakultas Ilmu dan Teknologi Kebumian, ITP, Bandung. 